\title{
Evaluasi Nutrien dan Kecernaan In Vitro Beberapa Spesies Rumput Lapangan Tropis di Indonesia
}

\author{
T. Wahyono ${ }^{1}$, E. Jatmiko ${ }^{2}$ Firsoni $^{1}$, S. N. W. Hardani ${ }^{1}$, E. Yunita ${ }^{2}$ \\ ${ }^{1}$ Laboratorium Nutrisi Ternak, Bidang Pertanian, Pusat Aplikasi Isotop dan Radiasi, Badan Tenaga Nuklir \\ Nasional, Jakarta Selatan, 12440 \\ ${ }^{2}$ Fakultas Sains dan Teknologi, Universitas Islam Negeri Syarif Hidayatullah, Jakarta, 15412 \\ Dikirim 03 Mei 2019; Diterima 28 Agustus 2019
}

\begin{abstract}
ABSTRAK
Tujuan dari penelitian ini adalah untuk melakukan evaluasi nutrisi dan kecernaan in vitro pada sembilan spesies rumput lapangan tropis di Indonesia. Sampel rumput lapangan diperoleh dari kebun rumput Kawasan Nuklir Pasar Jumat, Jakarta Selatan dengan metode kuadrat. Peletakan plot dilakukan secara purposive sampling dengan jumlah 15 plot (ukuran $1 \mathrm{x} 1 \mathrm{~m}$ ). Sembilan spesies rumput lapangan yang dievaluasi termasuk dalam famili Poaceae dan Cyperaceae. Peubah yang diamati adalah kandungan nutrien, fraksi serat, estimasi kecernaan dan in vitro true digestibility (IVTD). Rancangan yang digunakan adalah Rancangan Acak Lengkap (RAL) dengan empat pengulangan. Hasil penelitian menunjukkan bahwa Rumput Teki badot (Cyperus kyllinga) mengandung protein kasar (PK) tertinggi (7.60\%). Rumput Teki badot juga mengandung kadar neutral detergent fiber (NDF) dan acid detergent fiber (ADF) terendah berturut-turut sebesar $66.10 \%$ dan $32.40 \%(\mathrm{P}<0.05)$. Rumput Teki badot dan Rumput belulang (Eleusine indica) menghasilkan nilai relative feed value (RFV) tertinggi dan termasuk dalam kualitas hijauan "fair". Nilai IVTD tertinggi dihasilkan oleh Rumput Kusa-kusa (Echinochloa colonum) yaitu sebesar 66.62\% $(\mathrm{P}<0.05)$. Rumput Kusa-kusa dan Rumput teki badot merupakan dua spesies rumput lapangan yang potensial dikembangkan secara genetik karena memiliki kandungan nutrien serta kecernaan in vitro yang lebih tinggi dibandingkan spesies rumput lapangan tropis lainnya.
\end{abstract}

Kata kunci: Cyperus kyllinga, Kecernaan in vitro, Relative feed value, Rumput lapangan

\section{Nutrient Evaluation and In Vitro Digestibility of Various Species of Tropical Native Grass in Indonesia}

\begin{abstract}
The objectives of this study were to evaluate the nutrient and in vitro digestibility of nine native grass species in Indonesia. Native grass samples were collected from grass field of Pasar Jumat Nuclear Area. Area plot placement was done by purposive sampling with 15 plots $(1 \times 1 \mathrm{~m})$. Native grass species were including Poaceae and Cyperaceae family. Variables observed were nutrient content, fiber fraction, digestibility estimation and in vitro true digestibility (IVTD). Completely randomized design with four replication was used in this experiment. Results showed that Teki badot grass (Cyperus kyllinga) contained the highest crude protein $(C P)$ content (7.60\%). Teki badot grass also contained the lowest neutral detergent fiber $(N D F)$ and acid detergent fiber $(A D F)$ by $66.10 \%$ and $32.40 \%$ respectively $(P<0.05)$. Teki badot and Belulang grass (Eleusine indica) produced the highest relative feed value (RFV) and classified in "fair" forage quality. The highest IVTD value was produced by Kusa-kusa grass (Echinochloa colonum) by $66.62 \%(P<0.05)$. Kusa-kusa and Teki badot grass are two native grass species that have to be potential genetically developed due to the higher nutrient quality and in vitro digestibility than other native grass species.
\end{abstract}

Keywords: : Cyperus kyllinga, In vitro digestibility, Native grass, Relative feed value

\section{PENDAHULUAN}

Hijauan pakan adalah faktor penting dalam budidaya ternak ruminansia. Kondo et al. (2015) melaporkan bahwa penyediaan hijauan pakan sangat vital dalam usaha peternakan domba, kambing, sapi dan kerbau. Peternak rakyat masih banyak memanfaatkan limbah pertanian dan rumput sebagai sumber hijauan. Penggunaan limbah pertanian seperti jerami padi, lazim diberikan kepada ternak yang berada pada sentra pertanian (Wahyono et al., 2017). Kekurangan dari limbah pertanian adalah ketersediaannya yang tergantung musim panen dari budidaya tanaman pangan dan industri. Sebagai contoh jerami padi hanya

*Penulis Korespondensi: Teguh Wahyono

Alamat: Jl. Lebak Bulus Raya no. 49, Cilandak, Jakarta Selatan

E-mail: teguhwahyono@batan.go.id banyak tersedia di musim hujan sedangkan jerami/tebon jagung banyak terdapat pada musim kemarau.

Selain limbah pertanian, rumput lapangan masih menjadi andalan untuk memenuhi kebutuhan hijauan pakan di peternakan rakyat. Rumput lapangan merupakan sumber hijauan pakan yang umum di asia tenggara karena ketersediaannya yang melimpah selama musim hujan (Deutschmann et al., 2017). Sumber rumput lapangan yang dimanfaatkan oleh peternak banyak diperoleh dari area pematang sawah, perkebunan maupun sekitar jalan desa (Dismawan et al., 2014). Dari definisi di atas, rumput lapangan yang sering dimanfaatkan oleh peternak di Indonesia masih berupa campuran beberapa spesies liar (bukan budidaya). Rumput lapangan tropis di Indonesia memiliki komposisi nutrien yang bervariasi tergantung 
spesies dan kondisi lingkungannya (Evitayani et al., 2004).

Sebagai sumber pakan ternak, rumput harus memiliki kualitas baik, kecernaan tinggi, palatabilitas tinggi serta cukup ketersediaannya (Umami et al., 2017). Pernyataan tersebut merupakan dasar diperlukannya pengembangan genetik rumput lapangan untuk mendapatkan varian spesies rumput yang berkualitas. Ramírez et al. (2009) menjelaskan bahwa rumput lapangan merupakan objek studi hijauan pakan yang terus berkembang karena kelebihannya dalam beradaptasi dan mudah dibudidaya. Rumput lapangan yang berkualitas selanjutnya akan dikembangkan dan dibudidayakan secara intensif untuk mencukupi kebutuhan pakan ternak (Mburu et al., 2018). Evaluasi berbagai spesies rumput lapangan perlu dilakukan sebagai langkah awal dalam seleksi rumput pakan tropis di Indonesia. Evaluasi nutrien dan kecernan rumput tropis di musim hujan telah dilakukan di Filipina (Kondo et al., 2015). Mburu et al. (2018) memetakan profil nutrien dan kecernaan bahan kering di daerah pesisir dataran rendah di Kenya. Brown et al. (2018) memberikan informasi nutrien dan kecernaan in vitro rumput sub tropis. Potensi nutrien dan kecernaan berbagai spesies rumput lapangan di Indonesia belum banyak diteliti. Tujuan dari penelitian ini adalah untuk mengevaluasi kandungan nutrien, serat dan kecernaan in vitro dari sembilan spesies rumput lapangan tropis di Indonesia. Spesies rumput lapangan yang berpotensi, akan digunakan dalam pengembangan pemuliaan genetik rumput khusus pakan ternak.

\section{MATERI DAN METODE}

\section{Persiapan Bahan}

Pengambilan sampel rumput lapangan dilakukan di kebun rumput pakan ternak Kawasan Nuklir Pasar Jumat, Jakarta Selatan (6¹7'38.9” LS; $106^{\circ} 46^{\prime 2} 28.8^{\prime \prime}$ BT). Kondisi curah hujan tahunan 100$300 \mathrm{~mm}$ (85-150\% pada Februari-Juni 2018) dan suhu rata-rata $28,7^{\circ} \mathrm{C}$ (BMKG, 2018). Rumput teki badot (Cyperus kyllinga), Rumput pait (Axonopus compressus), Brabahan (Brachiaria sp.), Tapak jalak (Dactyloctenium aegyptium), Rumput kusa-kusa (Echinochloa colonum), Padi burung (Echinochloa crus-galli), Rumput belulang (Eleusine indica), Alangalang (Imperata cylindrica) dan Lamhani (Paspalum distichum) dikoleksi dengan metode kuadrat. Plot berukuran 1 x $1 \mathrm{~m}$ diletakkan secara purposive sampling sebanyak 10 buah pada masing-masing lokasi kebun. Rumput yang dikoleksi diperkirakan berumur 30-40 hari. Kesembilan sampel rumput dikeringkan pada suhu $60^{\circ} \mathrm{C}$ selama $48-72$ jam kemudian digiling sampai berukuran 1-2 mm. sampel kering kemudian dilakukan analisis kandungan nutrient dan in vitro true digestibility (IVTD).

Pengukuran Kandungan Nutrien dan Fraksi Serat Kandungan bahan organik (BO), abu, protein kasar (PK) dan lemak kasar (LK) dianalisis berdasarkan prosedur dalam AOAC (2005). Kandungan neutral detergent fiber (NDF), acid detergent fiber (ADF) dan acid detergent lignin (ADL) dianalisis menggunakan prosedur Van Soest et al. (1991). Kandungan hemiselulosa ditentukan dari persentase NDF-ADF. Kandungan selulosa ditentukan dari persentase ADFADL. Kandungan non fiber carbohydrate (NFC) dikalkulasi dari persentase BO-PK-NDF-LK.

\section{Perhitungan Estimasi Kecernaan}

Nilai estimasi dry matter digestibility (DMD), dry matter intake (DMI) dan relative feed value (RVF) ditentukan berdasarkan persamaan berikut:

$$
\begin{array}{ll}
\operatorname{DMD}(\%) & =88.9-(\% \mathrm{ADF} \times 0.779) \\
\operatorname{DMI}(\% \text { berat badan }) & =120 / \% \mathrm{NDF} \\
\operatorname{RFV}(\%) & =(\mathrm{DMD} \times \mathrm{DMI}) / 1.29
\end{array}
$$

(Kilic dan Gulecyuz, 2017; Rohweder et al., 1978)

Nilai RVF digunakan untuk menentukan kualitas hijauan pakan berdasarkan Quality Gradding Standard by The Hay Marketing Task Force of The American Forage and Grassland Council. Standar nilai hijauan pakan yang dimaksud adalah: reject (5) (skor<75), poor (4) (75-86), fair (3) (87-102), good (2) (103-124), premium (1) (125-151) dan prime (>151) (Kilic dan Gulecyuz 2017).

\section{Pengukuran In Vitro True Digestibility (IVTD)}

Pengukuran IVTD menggunakan instrumen Daisy II Incubator (Ankom Technology Corp, Fairport, $N Y$ ). Prosedur yang digunakan berdasarkan dalam metode Ankom (2017). Reagen yang digunakan adalah larutan A dan B. Pada $1000 \mathrm{ml}$ larutan A terdapat $10 \mathrm{~g}$ $\mathrm{KH}_{2} \mathrm{PO}_{4}, 0.5$ g $\mathrm{MgSO}_{4} .7 \mathrm{H}_{2} \mathrm{O}, 0.5 \mathrm{~g} \mathrm{NaCl}, 0.1 \mathrm{~g}$ $\mathrm{CaCl} .2 \mathrm{H}_{2} \mathrm{O}$ dan $0.5 \mathrm{~g}$ urea (reagent grade). Pada 1000 ml larutan B terdapat $15 \mathrm{~g} \mathrm{Na}_{2} \mathrm{CO}_{3}$ dan $1 \mathrm{~g} \mathrm{Na} 2 \mathrm{~S}_{9} 9 \mathrm{H}_{2} \mathrm{O}$. Pada satu tabung inkubator dapat digunakan untuk inkubasi 25 sampel. Pada satu buah instrumen Daisy ${ }^{I I}$ Incubator terdapat 4 buah tabung inkubator.

Cairan rumen sebagai inokulum diperoleh dari dua ekor sapi jantan Peranakan Ongole (PO) berfistula. Ransum sapi terdiri atas campuran rumput lapangan dan konsentrat dengan komposisi (50:50 BK). Pemberian pakan dilakukan dua kali sehari. Pengambilan cairan rumen dilakukan sebelum pemberian pakan pada pagi hari. Isi rumen disaring menggunakan kain kassa 4 lipatan dan cairannya dimasukkan ke dalam termos hangat $\left(39^{\circ} \mathrm{C}\right)$. Sebelum digunakan, cairan rumen diblender dan disuplai dengan gas $\mathrm{CO}_{2}$.

Sebanyak 0,5 g BK sampel (W2) dimasukkan ke dalam filter bag Ankom® (Ankom Technology F57) yang sebelumnya telah ditimbang beratnya (W1). Filter bag kosong juga dipersiapkan untuk digunakan sebagai faktor koreksi (C). Nilai faktor koreksi adalah berat filter bag kosong pasca inkubasi dibagi dengan berat awal. Sampel diinkubasi ke dalam cairan rumen-buffer yang telah dimasukkan ke dalam tabung inkubator. Kebutuhan cairan rumen-buffer dalam satu tabung 
inkubator (untuk 25 sampel) adalah $1330 \mathrm{ml}$ larutan A, $266 \mathrm{ml}$ larutan B (perbandingan A:B adalah 5:1) dan $400 \mathrm{ml}$ cairan rumen. Suplai gas $\mathrm{CO}_{2}$ dimasukkan ke tabung inkubator selama 30 detik sebelum proses inkubasi.

Proses inkubasi dilakukan selama 48 jam pada suhu $39.5 \pm 0.5{ }^{\circ} \mathrm{C}$. Sampel hasil inkubasi selanjutnya dipanaskan bersama reagen neutral detergent soluble (NDS) dalam Ankom 200 fiber analyzer ${ }^{\circledR}$ pada suhu $100^{\circ} \mathrm{C}$. Reagen yang digunakan adalah NDS $(2000 \mathrm{ml}$ per 24 sampel), sodium sulfite (20 g per $2000 \mathrm{ml} \mathrm{NDS}$ ) dan $4 \mathrm{ml}$ alpha-amylase. Proses pemanasan dilakukan selama 75 menit. Proses pembilasan dilakukan menggunakan akuades selama tiga kali pada suhu 70$90^{\circ} \mathrm{C}$ masing-masing selama lima menit. Sebanyak $4 \mathrm{ml}$ alpha-amylase ditambahkan pada pembilasan pertama dan kedua. Sampel yang telah dibilas kemudian direndam ke dalam aseton (250 ml per 24 sampel) selama 3-5 menit. Sampel kemudian diangin-anginkan dan dimasukkan ke dalam oven $100^{\circ} \mathrm{C}$ selama 2 jam. Sampel kemudian dimasukkan ke dalam plastik desikator dan ditimbang (W3). Nilai IVTD dapat ditentukan dengan rumus:

$$
\% \operatorname{IVTD}(\% \mathrm{BK})=\frac{100-(\mathrm{W} 3-(\mathrm{W} 1 \times \mathrm{C}))}{(\mathrm{W} 2 \times \% \mathrm{BK})} \times 100
$$

IVTD (in vitro true digestibility), $\mathrm{BK}$ (bahan kering), W1 (berat filter bag (g)), W2 (berat sampel awal (g)), W3 (berat sampel+filter bag pasca inkubasi (g)) dan C (faktor koreksi).

\section{Analisa Data}

Data yang dianalisis adalah data sembilan sampel rumput lapangan dengan menggunakan empat pengulangan. Data kandungan nutrien, estimasi kecernaan dan nilai IVTD dianalisis menggunakan oneway analysis of variance (ANOVA) dan dilanjutkan dengan Duncan Multiple Range Test (DMRT) jika terdapat perbedaan yang nyata. Analisis statistik dilakukan dengan bantuan program SPSS 20.0. Analisis korelasi juga dilakukan untuk mengetahui hubungan antara IVTD dengan kandungan nutrien beberapa spesies rumput lapangan (Steel dan Torrie, 1960).

\section{HASIL DAN PEMBAHASAN}

\section{Kandungan Nutrien dan Fraksi Serat}

Sembilan spesies rumput lapangan yang diamati adalah spesies rumput lapangan yang umum dijumpai dan digunakan sebagai hijauan pakan ternak di Indonesia. Kandungan nutrien dan serat kesembilan spesies rumput lapangan dapat dilihat pada Tabel 1 dan 2. Alang-alang mengandung kandungan $\mathrm{BK}$ dan $\mathrm{BO}$ tertinggi $(\mathrm{P}<0,05)$. Evitayani et al. (2004) melaporkan bahwa kandungan BO rumput adalah sekitar 86,2-92,2 $\%$. Dalam penelitian ini rerata kandungan BO rumput lapangan adalah sekitar 79,15-90,02\%. Perbedaan tersebut dapat disebabkan oleh perbedaan musim panen dan kandungan kontaminan yang dapat meningkatkan kadar abu. Kadar abu tertinggi dihasilkan oleh Padi burung namun tidak berbeda nyata dibandingkan Brabahan dan Rumput teki badot. Kilic dan Gulecyuz (2017) berpendapat bahwa tingginya kadar abu dapat menurunkan nilai nutrisi dari bahan pakan. Kadar abu merupakan representasi dari kandungan material anorganik pada pakan yang mungkin juga dipengaruhi oleh kontaminasi tanah disekitarnya (Mburu et al., 2018). Interpretasi tingginya kadar abu dapat diartikan menjadi dua hal yang kontradiktif yaitu: 1) tingginya kandungan mineral rumput yang dibutuhkan ternak atau 2) tingginya kandungan kontaminan pada rumput berupa tanah, pasir dan tanah liat yang menempel.

Alang-alang mengandung PK yang terendah dibandingkan kedelapan spesies lain. Kandungan PK tertinggi dihasilkan oleh rumput teki badot (7,60\%). Kandungan PK kesembilan spesies rumput lapangan berkisar antara 3,48-7,60\%. Jayanegara et al. (2017) melaporkan bahwa kebutuhan protein domba lokal dengan berat badan minimal $15 \mathrm{~kg}$ untuk meningkatkan berat badan minimal $50 \mathrm{~g} / \mathrm{hari}$ adalah sekiar 7,3\%. Berdasarkan hal tersebut, hanya Rumput teki badot yang dapat memenuhi standar. Kedelapan spesies rumput lapangan lain hanya dapat memenuhi kebutuhan hidup pokok domba, namun belum mendukung kebutuhan produksi. Kandungan PK Sembilan spesies rumput lapangan juga termasuk dalam kualitas yang rendah. Hal tersebut dinyatakan oleh Leng (1990) yang melaporkan bahwa hijuan yang mengandung PK $<8 \%$ termasuk dalam hijauan kualitas rendah. Berbagai penelitian telah melaporkan bahwa kandungan PK rumput di daerah tropis berkisar antara 11,1-11,7 \% (Evitayani et al., 2004), $11.5 \%$ (Dismawan et al., 2014) dan $10.8 \%$ (Kondo et al., 2015). Perbedaan kadar PK selain karena perbedaan spesies juga dapat disebabkan oleh pengaruh struktur tanah, pemupukan dan umur panen rumput (Kilic dan Gulecyuz, 2017). Perbedaan komposisi bagian tanaman seperti batang, daun dan malai juga dapat mempengaruhi kandungan PK yang dihasilkan.

Kandungan LK rumput kusa kusa lebih tinggi dibandingkan Rumput teki badot $(\mathrm{P}<0,05)$ namun tidak berbeda nyata dibandingkan tujuh spesies lain. Hal ini dapat disebabkan oleh tingginya proporsi malai dan biji pada rumput kusa-kusa dibandingkan rumput teki badot. Dalam struktur tanaman, kandungan LK banyak terdapat pada bagian biji (Mburu et al., 2018). Selain pada biji, kandungan LK juga dapat berada pada lapisan lilin pada daun. Lapisan ini terdapat pada beberapa spesies rumput di daerah tropis untuk meminimalisir evapotranspirasi. Umami et al. (2017) menjelaskan bahwa lapisan lilin pada permukaan daun berfungsi untuk mencegah kehilangan air akibat proses transpirasi. Dalam penelitian ini, kandungan LK rumput berkisar antara 0,41-3,11\%. Kondo et al. (2015) melaporkan bahwa kandungan LK rumput di daerah tropis berkisar antara 1,29-2,84\%. Evitayani et al. (2004) melaporkan bahwa rerata kandungan rumput di daerah tropis pada musim hujan adalah 2,0\% sedangkan pada musim kering sekitar 2,5\%. 
Kandungan NFC yang tertinggi dan terendah berturut-turut dihasilkan oleh Rumput belulang dan Padi burung $(\mathrm{P}<0,05)$. Fraksi NFC terdiri atas karbohidrat yang mudah terfermentasi, diantaranya pati dan gula sederhana. Kondo et al. (2015) melaporkan bahwa fraksi NFC merupakan elemen penting dalam mendukung proses pembentukan adenosine triphosphate (ATP) di dalam rumen untuk pembentukan protein mikroba. Dalam prosesnya, ATP dapat dibetuk dari karbohidrat struktural atau fraksi serat. Akan tetapi hal tersebut memerlukan waktu yang lebih lama dari NFC untuk terdegradasi. Berdasarkan hal tersebut, kandungan NFC adalah merupakan komponen penting untuk menilai kualitas suatu hijauan pakan. Dalam penelitian ini, Rumput belulang mengandung fraksi NFC tertinggi karena tingginya proporsi malai dan biji pada rumput tersebut. Selain kandungan LK, dalam biji tanaman juga banyak terkandung fraksi NFC. Hal yang kontradiktif dilaporkan oleh Rezaii et al. (2010), dimana fraksi NFC memiliki efek negatif dalam menurunkan kecernaan selulosa yang terkandung dalam pakan. Pola negatif tersebut disebabkan oleh penurunan $\mathrm{pH}$ akibat proses fermentasi fraksi NFC. Kondisi $\mathrm{pH}$ di bawah netral akan menurunkan kinerja bakteri selulase.
Kandungan NDF dan ADF tertinggi dihasilkan oleh rumput Lamhani $(\mathrm{P}<0,05)$. Rerata kandungan NDF dan ADF rumput lapangan dalam penelitian ini berturut-turut berkisar antara 66,16-78,51\% dan 30,1241,08\%. Evitayani et al. (2004) melaporkan bahwa kandungan NDF dan ADF rumput di daerah tropis berkisar pada $64,3 \%$ dan $34,6 \%$. Alang-alang dan Lamhani mengasilkan kandungan ADF yang berada pada kisaran 40\%. Hal tersebut lebih tinggi dibandingkan kandungan ADF jerami padi di daerah tropis yang berada pada kisaran 39\% (Kondo et al., 2015). Rumput teki badot, Rumput belulang dan Rumput kusa-kusa mengandung ADF yang paling rendah berturut turut sebesar 32,$49 ; 30,12$ dan $33,86 \%$. Nilai ADF ketiga rumput tersebut setara dengan kandungan ADF tanaman jagung yaitu sekitar 33,4\% (Kondo et al., 2015). Kandungan ADF yang rendah berkorelasi dengan tingginya tingkat kecernaan pakan. Kandungan NDF dan ADF suatu hijauan pakan dapat menjadi faktor pembatas dalam tingkat kecernaannya di dalam rumen. Kandungan NDF dan ADF hijauan pakan berkorelasi negatif dengan kecernaan nutrien dan besaran energi yang termetabolis (Stergiadis et al., 2015). Kilic dan Gulecyuz (2017) melaporkan bahwa kandungan NDF dan ADF yang rendah dapat meningkatkan kelas kualitas hijauan. Fraksi NDF

Tabel 1. Kandungan nutrien beberapa spesies rumput lapangan tropis di Indonesia

\begin{tabular}{lccccc}
\hline \multirow{2}{*}{ Jenis rumput lapangan } & \multirow{2}{*}{ BK $(\%)$} & \multicolumn{4}{c}{ Kandungan Nutrien $(\% \mathrm{BK})$} \\
\cline { 3 - 6 } & & $\mathrm{BO}$ & Abu & PK & LK \\
\hline Rumput teki badot & $22,99^{\mathrm{a}}$ & $81,60^{\mathrm{abc}}$ & $18,39^{\mathrm{def}}$ & 7,60 & $0,41^{\mathrm{a}}$ \\
Rumput pait & $29,01^{\mathrm{ab}}$ & $83,01^{\mathrm{cd}}$ & $16,99^{\mathrm{cd}}$ & 7,05 & $1,71^{\mathrm{ab}}$ \\
Brabahan & $39,54^{\mathrm{bc}}$ & $79,68^{\mathrm{ab}}$ & $20,32^{\mathrm{ef}}$ & 5,90 & $2,13^{\mathrm{ab}}$ \\
Tapak jalak & $36,53^{\mathrm{bc}}$ & $82,29^{\mathrm{bc}}$ & $17,71^{\mathrm{de}}$ & 4,70 & $1,54^{\mathrm{ab}}$ \\
Rumput kusa-kusa & $33,25^{\mathrm{bc}}$ & $85,24^{\mathrm{de}}$ & $14,76^{\mathrm{bc}}$ & 6,75 & $3,11^{\mathrm{b}}$ \\
Padi burung & $36,82^{\mathrm{bc}}$ & $79,15^{\mathrm{a}}$ & $20,85^{\mathrm{f}}$ & 6,35 & $1,37^{\mathrm{ab}}$ \\
Rumput belulang & $29,69^{\mathrm{b}}$ & $88,99^{\mathrm{f}}$ & $11,01^{\mathrm{a}}$ & 7,00 & $1,60^{\mathrm{ab}}$ \\
Alang-alang & $44,13^{\mathrm{e}}$ & $90,02^{\mathrm{f}}$ & $9,98^{\mathrm{a}}$ & 3,48 & $1,57^{\mathrm{ab}}$ \\
Lamhani & $41,13^{\mathrm{de}}$ & $87,47^{\mathrm{ef}}$ & $12,53^{\mathrm{ab}}$ & 4,27 & $1,70^{\mathrm{ab}}$ \\
SEM & 1,290 & 0,773 & 1,325 & 0,251 & 0,090 \\
\hline
\end{tabular}

a,b,c,d,e,f superskrip yang berbeda pada kolom yang sama menunjukkan perbedaan yang nyata $(\mathrm{P}<0,05)$. BK (bahan kering), BO (bahan organik), PK (protein kasar), LK (lemak kasar). SEM (standard error mean). *Tidak dilakukan pengulangan pada peubah PK, sehingga tidak dilakukan analisis statsitik.

Tabel 2. Kandungan fraksi serat beberapa spesies rumput lapangan tropis di Indonesia

\begin{tabular}{lcccccc}
\hline \multirow{2}{*}{ Jenis rumput lapangan } & \multicolumn{5}{c}{ Kandungan Nutrien (\% BK) } \\
\cline { 2 - 6 } & NFC & NDF & ADF & ADL & Hemiselulosa & Selulosa \\
\hline Rumput teki badot & $7,43^{\mathrm{c}}$ & $66,16^{\mathrm{a}}$ & $32,49^{\mathrm{b}}$ & $8,04^{\mathrm{d}}$ & $33,67^{\mathrm{c}}$ & $24,45^{\mathrm{a}}$ \\
Rumput pait & $6,71^{\mathrm{c}}$ & $67,54^{\mathrm{ab}}$ & $36,79^{\mathrm{c}}$ & $4,90^{\mathrm{a}}$ & $30,75^{\mathrm{a}}$ & $31,89^{\mathrm{d}}$ \\
Brabahan & $3,05^{\mathrm{ab}}$ & $69,41^{\mathrm{bc}}$ & $37,79^{\mathrm{cd}}$ & $5,54^{\mathrm{abc}}$ & $31,61^{\mathrm{b}}$ & $32,25^{\mathrm{d}}$ \\
Tapak jalak & $5,68^{\mathrm{bc}}$ & $70,36^{\mathrm{c}}$ & $36,30^{\mathrm{c}}$ & $9,84^{\mathrm{e}}$ & $34,06^{\mathrm{c}}$ & $26,45^{\mathrm{bc}}$ \\
Rumput kusa-kusa & $6,16^{\mathrm{bc}}$ & $69,21^{\mathrm{bc}}$ & $33,86^{\mathrm{b}}$ & $6,27^{\mathrm{bc}}$ & $35,35^{\mathrm{d}}$ & $27,59^{\mathrm{c}}$ \\
Padi burung & $2,59^{\mathrm{a}}$ & $70,12^{\mathrm{c}}$ & $38,79^{\mathrm{de}}$ & $6,60^{\mathrm{c}}$ & $31,33^{\mathrm{ab}}$ & $32,19^{\mathrm{d}}$ \\
Rumput belulang & $12,75^{\mathrm{d}}$ & $67,63^{\mathrm{ab}}$ & $30,12^{\mathrm{a}}$ & $5,19^{\mathrm{ab}}$ & $37,51^{\mathrm{e}}$ & $24,93^{\mathrm{ab}}$ \\
Alang-alang & $5,95^{\mathrm{bc}}$ & $78,51^{\mathrm{e}}$ & $40,37^{\mathrm{ef}}$ & $6,45^{\mathrm{bc}}$ & $38,14^{\mathrm{e}}$ & $33,93^{\mathrm{e}}$ \\
Lamhani & $6,27^{\mathrm{c}}$ & $75,23^{\mathrm{d}}$ & $41,08^{\mathrm{f}}$ & $5,92^{\mathrm{abc}}$ & $34,15^{\mathrm{c}}$ & $35,15^{\mathrm{e}}$ \\
SEM & 0,602 & 0,740 & 0,682 & 0,306 & 0,489 & 0,759 \\
\hline a,b,c,d,e,f superskrip yang berbeda pada kolom yang sama menunjukkan perbedaan yang nyata (P<0,05). BK (bahan kering), NFC \\
(non fiber carbohydrate), NDF (neutral detergent fiber), ADF (acid detergent fiber), ADL (acid detergent lignin). SEM \\
(standard error mean).
\end{tabular}


terdiri dari struktur hemiselulosa, selulosa dan lignin. Wahyono et al. (2017) menjelaskan bahwa dalam hijauan pakan terdapat ikatan lignin-selulosa dan lignin-hemiselulosa yang merupakan penghambat degradasi pakan di dalam rumen.

Tapak jalak mengandung kadar ADL tertinggi dibandingkan kedelapan spesies lain $(\mathrm{P}<0,05)$. Rumput belulang dan Alang-alang mengandung kadar hemiselulosa tertinggi $(\mathrm{P}<0,05)$. Kadar selulosa tertinggi ditunjukkan oleh spesies Lamhani dan Alangalang $(\mathrm{P}<0,05)$. Pengukuran lignin dalam bentuk ADL diperlukan karena adanya asosiasi lignin dengan selulosa dan hemiselulosa dalam fraksi serat. Rumput pait mengandung kadar ADL yang terendah dalam penelitian ini $(4,90 \%)$. Nilai tersebut lebih rendah dibandingkan dalam penelitian Evitayani et al. (2004), dimana kandungan ADL Rumput pait berkisar antara 4,8 - 6,5\%. Kandungan ADL pada berbagai spesies rumput tropis berkisar antara 3,50 - 4,94\% (Kondo et al., 2015). Dalam penelitian ini, kandungan ADL berkisar antara 4,90-8,04\%. Perbedaan kandungan ADL dengan beberapa referensi dapat disebabkan oleh perbedaan umur panen tanaman. Tingginya konsentrasi lignin akan berdampak terhadap penurunan kecernaan bahan NDF. Akan tetapi, masih banyak faktor yang mempengaruhi kecernaan nutrien selain lignin. Hal tersebut membuat mekanisme lignin yang menghambat pencernaan masih sering dikaji sampai saat ini (Turano et al., 2016).

\section{Estimasi Kecernaan dan IVTD}

Evaluasi kecernaan in vitro dilakukan menggunakan metode inkubasi batch culture Daisy ${ }^{I I}$ Incubator (Ankom Technology Corp, Fairport, NY). Kelebihan metode tersebut adalah praktis, akurat dan berkorelasi dengan uji in vivo (Ludwin et al., 2005;
Rofiq et al., 2015). Nilai estimasi kecernaan dan IVTD dari sembilan spesies rumput lapangan yang diamati dapat dilihat pada Tabel 3. Rumput teki badot dan Rumput belulang manghasilkan nilai RFV tertinggi, berturut-turut sebesar 89,41 dan 88,30 ( $\mathrm{P}<0,05)$. Nilai RFV tersebut termasuk dalam kisaran kualitas hijauan fair.

Prediksi kecernaan dan kualitas nutrisi suatu bahan pakan dapat ditentukan berdasarkan komposisi nutrisi yang ada di dalamnya. Kadar NDF dan ADF adalah dua komponen penting dalam menentukan estimasi nilai nutrisi suatu bahan pakan (Stergiadis et al., 2015). Kilic dan Gulecyuz (2017) melaporkan bahwa rendahnya kandungan NDF dan ADF akan meningkatkan indeks RFV hijauan pakan. Hal tersebut dibuktikan oleh tingginya indeks RFV karena kadar NDF dan ADF yang rendah pada Rumput teki badot dan Rumput belulang. Kedua rumput tersebut termasuk dalam kategori "fair" dan berada satu tingkat dibawah kualitas hijauan sorgum dan jagung. Belum banyak studi tentang indeks RFV rumput tropis di Indonesia, sehingga komparasi studi dalam penelitian ini menggunakan data dari luar Indonesia. Jahansouz et al. (2014) melaporkan bahwa hijauan sorgum dan jagung di daerah tropis berada pada kategori hijauan "good" dengan indeks RFV berturut-turut sebesar 108,7 dan 123,9. Rumput Brabahan dalam penelitian ini menghasilkan indeks RFV sebesar 79,69. Hal tersebut sesuai dengan penelitian Suhaimi et al. (2017) yang melaporkan bahwa kisaran nilai RFV rumput Brabahan adalah sekitar 74,83-84,17.

Estimasi nilai kecernaan perlu divalidasi menggunakan pengujian di laboratorium. Nilai IVTD merupakan hasil pengujian untuk menentukan nilai kecernaan di dalam rumen secara in vitro. Nilai IVTD Rumput kusa-kusa lebih tinggi dibandingkan Alang-

Tabel 3. Nilai estimasi kecernaan dan IVTD rumput lapangan tropis di Indonesia

\begin{tabular}{lccc}
\hline \hline \multirow{2}{*}{ Jenis rumput lapangan } & \multicolumn{3}{c}{ Kandungan Nutrien (\% BK) } \\
\cline { 2 - 3 } & RFV & Forage Quality & IVTD $(\%)$ \\
\hline Rumput teki badot & $89,41^{\mathrm{e}}$ & Fair & $65,12^{\mathrm{bc}}$ \\
Rumput pait & $82,98^{\mathrm{cd}}$ & Poor & $62,91^{\mathrm{bc}}$ \\
Brabahan & $79,69^{\mathrm{bc}}$ & Poor & $59,67^{\mathrm{bc}}$ \\
Tapak jalak & $80,16^{\mathrm{bcd}}$ & Poor & $60,79^{\mathrm{bc}}$ \\
Rumput kusa-kusa & $84,03^{\mathrm{d}}$ & Poor & $66,68^{\mathrm{c}}$ \\
Padi burung & $77,85^{\mathrm{b}}$ & Poor & $65,41^{\mathrm{bc}}$ \\
Rumput belulang & $88,30^{\mathrm{e}}$ & Fair & $63,45^{\mathrm{bc}}$ \\
Alang-alang & $68,06^{\mathrm{a}}$ & Reject & $49,34^{\mathrm{a}}$ \\
Lamhani & $70,36^{\mathrm{a}}$ & Reject & $55,06^{\mathrm{b}}$ \\
SEM & 1,411 & & 1,300 \\
\hline abc,e & &
\end{tabular}

$\overline{\text { a,b,c,d,e }}$ superskrip yang berbeda pada kolom yang sama menunjukkan perbedaan yang nyata $(\mathrm{P}<0,05)$. BK (bahan kering), $\mathrm{RFV}$ (relative feed value), IVTD (in vitro true digestibility). SEM (standard error mean).

Tabel 4. Matriks korelasi antara IVTD dengan kandungan nutrien rumput lapangan

\begin{tabular}{lccccc}
\hline \hline & \multicolumn{4}{c}{ Kandungan Nutrien } \\
\cline { 2 - 6 } & BO & PK & LK & NDF & ADF \\
\hline IVTD & $-0,674^{*}$ & $0,776^{*}$ & $0,131^{\text {tn }}$ & $-0,762^{*}$ & $-0,576^{*}$ \\
\hline${ }^{*}$ berbeda nyata $(\mathrm{P}<0,05){ }^{\text {tn }}$ tidak berbeda nyata. BK (bahan kering), BO (bahan organik), PK (protein kasar), LK (lemak kasar),
\end{tabular}

${ }^{*}$ berbeda nyata $(\mathrm{P}<0,05),{ }^{\text {tn }}$ tidak berbeda nyata. BK (bahan kering), BO (bahan organik), PK (protein kasar), LK (lemak kasar), $\mathrm{NDF}$ (neutral detergent fiber), ADF (acid detergent fiber). IVTD (in vitro true digestibility). 
alang dan Lamhani $(\mathrm{P}<0,05)$, namun tidak berbeda nyata jika dibandingkan dengan spesies rumput lapangan lain. Nilai IVTD memiliki korelasi dengan profil nurien yang sebelumnya telah dianalisis. Matriks korelasinya dapat dilihat pada Tabel 4. Nilai IVTD memiliki korelasi positif dengan kandungan PK ( $\mathrm{r}=$ 0,78 ), akan tetapi bernilai negatif dengan kandungan $\mathrm{NDF}$ dan ADF $(\mathrm{r}=-0,76$ dan $\mathrm{r}=-0,58)$. Hal tersebut sesuai dengan pendapat Stergiadis et al. (2015) yang menyatakan bahwa kecernaan nutrien pakan berkorelasi negatif dengan fraksi serat berupa NDF dan ADF.

Rumput kusa-kusa menghasilkan nilai IVTD yang tinggi karena memiliki kandungan ADF dan selulosa yang cukup rendah (Tabel 2). Semakin rendah kandungan fraksi serat akan meningkatkan efisiensi penggunaan energi untuk degradasi pakan. Hal tersebut akan meningkatkan nilai kecernaannya. Umami et al. (2017) melaporkan bahwa tinggginya komponen serat dalam pakan dapat menghambat kecernaan fraksi lain dalam pakan. Hal tersebut karena energi yang dibutuhkan untuk mencerna selulosa, hemiselulosa dan lignin cukup besar. Kondo et al. (2015) menjelaskan bahwa kandungan ADF berkorelasi negatif $(\mathrm{r}=-0,47)$ dengan pembentukan volatile fatty acids (VFA) di dalam rumen. Pembentukan VFA yang terhambat di rumen akan menurunkan degradasi nutrien secara umum. Kandungan ADF berkorelasi negatif dengan kecernaan bahan organik pakan (Jayanegara et al., 2009). Rumput teki badot menghasilkan nilai IVTD yang tinggi karena mengandung PK yang tinggi. Jayanegara et al. (2009) melaporkan bahwa kecernaan nutrien pakan berkorelasi positif $(\mathrm{r}=0,98)$ dengan kandungan PK. Alang-alang menghasilkan IVTD yang terendah karena memiliki kandungan PK yang rendah ditambah dengan kandungan NDF, ADF dan selulosa yang tinggi (Tabel 1 dan 2). Evitayani et al. (2004) menjelaskan bahwa kombinasi kandungan serat yang tinggi dan PK yang rendah akan berdampak kepada rendahnya nilai kecernaan suatu bahan pakan.

\section{KESIMPULAN}

Kandungan PK sembilan spesies rumput lapangan berada pada kisaran 3,48-7,60\% dengan nilai tertinggi dihasilkan oleh Rumput teki badot. Dari kualitas fraksi serat, Rumput belulang mengandung kadar NFC tertinggi dan ADF terendah. Rumput belulang dan Rumput teki badot merupakan dua spesies rumput yang masuk dalam kategoi kualitas 'fair' berdasarkan perhitungan estimasi RFV. Akan tetapi, Nilai IVTD tertinggi dihasilkan oleh Rumput Kusakusa yaitu sebesar $66.62 \%$. Rumput Kusa-kusa dan Rumput teki badot adalah dua spesies rumput lapangan yang potensial dikembangkan secara genetik karena memiliki profil nutrien serta kecernaan in vitro yang lebih tinggi dibandingkan tujuh spesies rumput lapangan tropis lainnya. Dalam penelitian ini juga ditemukan bahwa kecernaan in vitro rumput lapangan berkorelasi negatif dengan kandungan NDF dan ADF.
Kecernaan in vitro juga memiliki nilai korelasi postitif dengan kandungan PK. Dalam penelitian selanjutnya, perlu dilakukan evaluasi profil nutrien dan kecernaan rumput lapangan yang dipanen pada musim yang berbeda.

\section{KESIMPULAN}

Penulis mengucapkan terima kasih kepada Bapak Dedi Ansori, Ibu Yunida Maharani, A.Md dan segenap staf laboratorium Nutrisi Ternak PAIR BATAN atas bantuan teknis selama penelitian.

\section{DAFTAR PUSTAKA}

Ankom. 2017. In vitro true digestibility using the DAISYII incubator. https://www.ankom.com/sites/default/files/doc ument-files/D200_D200I_Manual.pdf. Accessed 24 April 2019.

AOAC. 2005. Official Method of Analysis. 18th ed. Association of Official Analytical Chemists, Chemists, Arlington, VA, USA.

BMKG. Badan Meteorologi, Klimatologi dan Geofisika. 2018. Climate analyze. https://www.bmkg.go.id/iklim/informasi-hujanbulanan.bmkg. Diakses 21 September 2018.

Brown, A. N., G. Ferreira, C. L. Teets, W. E. Thomason and C. D. Teutsch. 2018. Nutritional composition and in vitro digestibility of grass and legume winter (cover) crops. Journal of Dairy Science 101(3): 2037-2047.

Deutschmann, K., C. Phatsara, C. Sorachakula, T. Vearasilp, W. Phunphiphat, A. Cherdthong, K. Gerlach and K.H. Südekum. 2017. In vitro gas production and in vivo nutrient digestibility and growth performance of thai indigenous cattle fed fresh and conserved pangola grass. Italian Journal of Animal Science 16(3): 521-529.

Dismawan, I. Wayan Heri, I. Ketut Ginantra and Ni Luh Suriani. 2014. Seleksi jenis tumbuhan pakan dan kandungan nutrien jenis tumbuhan yang dimakan sapi bali (Bos sondaicus) lepas sapih di daerah bukit badung selatan, kabupaten Badung, Bali. Jurnal Simbiosis II(2): 192-202.

Evitayani, L. Warly, A. Fariani, T. Ichinohe and T. Fujihara. 2004. Seasonal changes in nutritive value of some grass species in west sumatra, Indonesia. Asian-Australasian Journal of Animal Science 17(12): 1663-1668.

Jahansouz, M. R., R. K. Afshar, H. Heidari and H. Masoud. 2014. Evaluation of yield and quality of sorghum and millet as alternative forage crops to corn under normal and deficit irrigation regimes. Jordan Journal of Agricultural Sciences 10(4): 699-714.

Jayanegara, A., M. Ridla, D. A. Astuti, K. G. Wiryawan and E. B. Laconi. 2017. Determination of energy and protein requirements of sheep in Indonesia 
using a meta-analytical approach. Media Peternakan 40(2): 118-127.

Jayanegara, A., A. Sofyan, H. P. S. Makkar and K. Becker. 2009. Kinetika produksi gas, kecernaan bahan organik dan produksi gas metana in vitro pada hay dan jerami yang disuplementasi hijauan mengandung tanin. Media Peternakan 32(2): 120-129.

Kilic, U. and E. Gulecyuz. 2017. Effects of some additives on in vitro true digestibility of wheat and soybean straw pellets. Open Life Sciences 12: 206-213.

Kondo, M., M. Yoshida, M. Loresco, M. L. Lapitan, J. Rommel, V. Herrera, A. N. D. Barrio, Y. Uyeno, H. Matsui and T. Fujihara. 2015. Nutrient contents and in vitro ruminal fermentation of tropical grasses harvested in wet season in the Philippines. Advances in Animal and Veterinary Sciences 3(12): 694-699.

Leng, R. A. 1990. Factors affecting the utilization of 'poor-quality' forages by ruminants particulary under tropical conditions. Nutrition Research Reviews 3: 277-303.

Ludwin, J., Z. M. Kowalski and M. R. Weisbjerg. 2005. The use of the in vitro filter bag method for predicting digestibility of forages. Journal of Animal and Feed Sciences 14(Suppl 1): 571574.

Mburu, L. M., C. K. Gachuiri, M. M. Wanyoike and J. D. Mande. 2018. Forage and in vitro dry matter digestibility quality of native species in coastal lowlands of Kenya. International Journal of Animal Science 2(6): 1-5.

Ramírez, R. G., H. Gonzalez-Rodríguez, R. MoralesRodríguez, A. Cerrillo-Soto, A. Juarez-Reyes, G. J. García-Dessommes and M. GuerreroCervantes. 2009. Chemical composition and dry matter digestion of some native and cultivated grasses in Mexico. Czech Journal of Animal Science 54(4): 150-162.

Rezaii, F., M. Danesh Mesgaran and A. R. Heravi Mousavi. 2010. Effect of non-fiber carbohydrates on in vitro first order kinetics disappearance of cellulose. Iranian Journal of Veterinary Research 11(2): 139-144.

Rofiq, M. N., S. Martono, M. Surachman and I. W. Angga D. 2015. Kualitas nutrisi dan kecernaan nyata bahan kering in vitro (ivtdmd) pakan hijauan cover crop kebun sawit untuk ternak ruminansia di kabupaten Pelalawan. Jurnal Sains Dan Teknologi Indonesia 17(1): 1-6.

Rohweder, D. A., R. F. Barnes and N. Jorgensen. 1978. Proposed hay grading standards based on laboratory analyses for evaluating quality. Journal of Animal Science 47(3): 747-759.

Steel, R. G. D. and J. H. Torrie. 1980. Principles and Procedures of Statistics. A Biometrical Approach. 2nd ed. McGraw-Hill, New York, USA.
Stergiadis, S., M. Allen, X. J. Chen, D. Wills and T. Yan. 2015. Prediction of nutrient digestibility and energy concentrations in fresh grass using nutrient composition. Journal of Dairy Science 98(5): 3257-3273.

Suhaimi, D., S. Sharif, M. A. Normah, M. N. Nadia and H. W. Syahidah. 2017. Estimating relative feed value of local brachiaria decumbens. Malaysian Journal of Veterinary Research 8(2): 78-82.

Turano, B., U. P. Tiwari and R. Jha. 2016. Growth and nutritional evaluation of napier grass hybrids as forage for ruminants. Tropical Grasslands 4(3): $168-178$

Umami, N., A. N. Respati, B. Suhartanto and N. Suseno. 2017. Nutrient composition and in vitro digestibility of Brachiaria decumbens cv. basilisk with different level of fertilizer. In : Proceedings of the 7th International Seminar on Tropical Animal Production. Yogyakarta, Indonesia. pp. 143-146.

Van Soest, P. J., J. B. Robertson and B. A. Lewis. 1991. Methods for dietary fiber, neutral detergent fiber, and nonstarch polysaccharides in relation to animal nutrition. Journal of Dairy Science 74: 3583-3597.

Wahyono, T., N. Lelananingtyas and Sihono. 2017. Effects of gamma irradiation on ruminal degradation of samurai 1 sweet sorghum bagasse. Atom Indonesia 43(1): 35-39.

Wahyono, T., I. A. Rizqi, L. O. Sumarlin, T. R. D. Larasati and Suharyono. 2017. Pengaruh ukuran partikel dan fermentasi menggunakan aspergillus niger yang telah diiradiasi terhadap degradabilitas in sacco jerami padi. Buletin Peternakan 41(3): 271-278. 